\title{
A potential nursing ground for the southern right whale Eubalaena australis in northern Chile
}

\author{
Ana M. García-Cegarra ${ }^{1,2^{*}}$, Maritza Malebran ${ }^{1}$, Koen Van Waerebeek ${ }^{3,4,5}$
}

${ }^{1}$ Centro de Investigación de Fauna Marina y Avistamiento de Cetáceos (CIFAMAC), Mejillones, Chile.

${ }^{2}$ Departamento de Ciencias Básicas, Facultad de Ciencias, Universidad Santo Tomás, Antofagasta, Chile.

${ }^{3}$ Centro Peruano de Estudios Cetológicos (CEPEC), Pucusana, Lima-20, Perú

${ }^{4}$ Centre for Marine Mammals Research Leviathan (CMMR), Santiago, Chile

${ }^{5}$ Center for The Chinese White Dolphin Research and Conservation, Beijing Institute of Technology, Zhuhai, 6 Jinfeng Road, Zhuhai City, 51900, Guangdong, PR China

* Corresponding author: Koen Van Waerebeek: corewam@yandex.com

\begin{abstract}
The Chile-Peru subpopulation $(\mathrm{CPe})$ of the southern right whale (Eubalaena australis) is classified as critically endangered following intense whaling in past centuries. Due to their very low abundance, information on breeding and feeding grounds is also scarce. Unmanned aerial vehicles (UAVs) are increasingly applied in marine mammal research thanks to their low cost and relative ease of use. This case study documents a southern right whale nursing in Bahía Moreno ( $\left.23^{\circ} \mathrm{S}\right)$, Antofagasta, northern Chile, through high-resolution images taken by UAV of a lone adult in July 2019 and the same (photo-identified) whale with a neonate in August, confirming local parturition. Combined with earlier data we hypothesize that the Antofagasta Region may be a calving and nursing ground for the CPe subpopulation. Given the intense shipping traffic and fishing activities around the Mejillones Peninsula and Antofagasta port, priorly recommended marine spatial planning to help avoid net entanglements and vessel collisions of fin and humpback whales would also contribute to the conservation of the CPe stock of southern right whale.
\end{abstract}

Keywords: Breeding, nursery gound, Eubalaena australis, Chile, Humboldt Current System, mark-recapture, drone. 
The Southeast Pacific population of the southern right whale (Eubalaena australis), also referred to as the Chile-Peru subpopulation (CPe), experienced a detrimental decline due to intense commercial whaling conducted between 1789 and 1976 with around 9000 individuals hunted (Clarke, 1965; Aguayo-Lobo et al., 1998; Pastene and Quiroz, 2010). Despite an international moratorium established in 1936 prohibiting the hunting of southern right whales (SRW), in Chile hunting continued for another 40 years, with the last SRW taken in 1976 (Aguayo-Lobo and Torres, 1986). The unsustainable exploitation led them to near extinction and currently the CPe subpopulation of SRW is considered critically endangered with fewer than 50 mature individuals (Reilly et al., 2008; Cooke, 2018). In contrast, the geographically closest western South Atlantic SRW subpopulation has experienced strong growth over the past few decades in the shallow coastal waters of Argentina and Uruguay (Cooke et al., 2001; Piedra et al., 2006).

On the west coast of South America, the CPe subpopulation of SRW are distributed from Lima, central Peru ( $12^{\circ} 11^{\prime}$ S) to $47^{\circ} 58^{\prime} \mathrm{S}$, Gulf of Penas, austral Chile (Aguayo-Lobo, 1974; Van Waerebeek et al., 1992, 2009; Orihuela and Cortegana-Arias, 2013; GallettiVernazzani et al., 2014). Off Chile two main aggregation areas have been recognized, one in the Antofagasta Region, northern Chile (centred around $23^{\circ} \mathrm{S}$ ) and another in central-south Chile $\left(33^{\circ} \mathrm{S}\right.$ to $\left.42^{\circ} \mathrm{S}\right)$ (Guerra-Correa et al., 1987; Galletti-Vernazzani et al., 2014). The whales are thought to migrate annually from feeding grounds at high latitudes off the Antarctic Peninsula to breeding and nursing grounds at low latitudes in Chile and Peru (Mackintosh, 1942; Aguayo-Lobo et al., 1992; Aguayo-Lobo et al., 2008; Van Waerebeek et al., 1998, 2009). However, based on geographical considerations Gibbons et al. (2006) proposed that SRW found in Antarctica and Magellanes Strait correspond to individuals from the Southwest Atlantic population. Aguayo-Lobo et al. (2008) suggested the Magallanes Region and Antarctic waters as feeding grounds for, respectively, the Argentina and the $\mathrm{CPe}$ subpopulations. Much uncertainty remains. Moreover the classic paradigm of obligate seasonal migrations of baleen whale species for feeding purposes is under increasing controversy as new studies (e.g. Weerdt and Ramos, 2019; Frisch-Jordán et al., 2019) support earlier findings of occasional non-migrating humpback whales in upwelling areas and feeding on breeding grounds (Papastavrou and Van Waerebeek, 1998). Also, some fin whales (Balaenoptera physalus) in the Gulf of California were found not migrating to higher latitudes to feed (Jiménez-López et al., 2019). As the SRW CPe subpopulation has not recovered from whaling and sightings are scarce, their migratory paths, breeding and nursery grounds in the Southeast Pacific are poorly known. 
Mother-calf pairs have been observed along the Peruvian and Chilean coasts on several occasions (Cardenas et al., 1986; Van Waerebeek et al., 1998, 2009; Santillán et al., 2004; Galletti-Vernazzani et al., 2014). With five cases of mother-calf (neonate) pairs among seven confirmed occurrences, southern and central Peruvian coastal waters are now firmly established as native for SRW (Van Waerebeek et al., 2009). The northernmost mother-calf pair was observed off Chorrillos, Lima (12 $11^{\prime}$ S) on 21 August 2012 (Orihuela and Cortegana-Arias, 2013) and the southernmost about $18 \mathrm{nmi}$ north of Isla de Chiloé (41 $\left.27^{\circ} \mathrm{S}\right)$ in October 2010 (Galletti-Vernazzani et al., 2014). Mother-calf pairs have been reliably

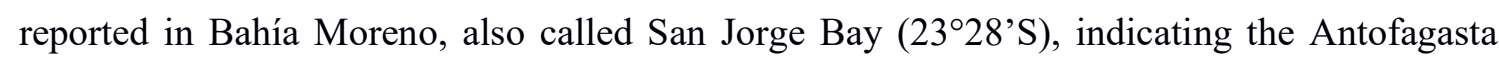
Region as a potential nursing ground for the CPe subpopulation (Cardenas et al., 1986; Guerra-Correa et al., 1987; Galletti-Vernazzani et al., 2011, 2014). The breeding season is suggested to last from June to October (Aguayo-Lobo et al., 2008) and a maximum residency time of three months is recorded in Chile (Canto et al., 1991). Parturition has not been documented on potential nursing grounds of the CPe subpopulation. However, locals in Atico, Peru, convincingly described a nearshore parturition in early August, when (postpartum) bleeding was noted at the moment a calf first appeared. The mother-calf pair then stayed in the area for 66 days (Van Waerebeek et al., 1998). Here we present a new case of a SRW mother-calf pair, observed before and after parturition and documented by an unmanned aerial vehicle (UAV) in 2019. It adds evidence to the notion of the Antofagasta Region as a nursing ground for the CPe subpopulation (Galletti-Vernazzani et al., 2011, 2014).

The recreational use of UAVs is increasing rapidly among citizens due to its low cost and ease of use (Teal Group Corporation, 2011). UAVs are also becoming effective tools for wildlife research and monitoring considering their friendly and safe handling (Nowacek et al., 2016). Launched from land or sea, they have the potential to collect high-resolution images and videos of inaccessible and elusive wildlife such as marine mammals (Koski et al., 2013) where they have been deployed to monitor abundance, photo ID, photogrammetry, body condition and to collect breath samples for disease monitoring (Christiansen et al., 2019). Although it has been demonstrated that UAVs may negatively affect the behavior of sea otters (Enhydra lutris) and pinnipeds due to noise-levels (Richardson et al., 1995), negative effects have not been found in the behavior of baleen whales (Acevedo-Whitehouse et al., 2010). Thus, UAVs are considered a non-invasive tool to successfully implement photo identification and photogrammetry of baleen whales (Koski et al., 2013; Christiansen et al., 2019, 2020). 


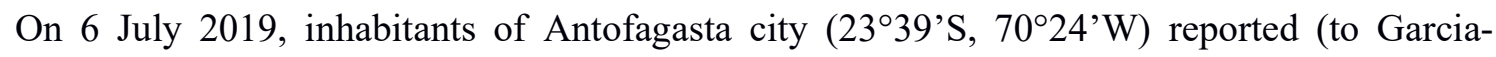
Cegarra) an adult whale moving slowly south of the city, so close to shore that its blows were readily seen from land. The species was identified as a SRW thanks to its unmistakable external morphology including a broad back, callosities on the head and the lack of a dorsal fin.

On 8 July 2019, a single adult SRW was observed south of Antofagasta city by local citizens during the Antofagasta Body Board Festival. In small populations SRW sightings in close proximity, both time and locations, are considered same individuals (Patenaude 2003). Hence, the individual observed on 8 July was probably the same individual seen on 6 July (Figure 1, \#1). With the use of an UAV the locals obtained high-resolution images, which allowed us to photo-identify the whale by the characterization of the head callosities and the location and shape of a large white blaze on its dorsum (Figure 2a). The unaccompanied individual was observed swimming slowly during consecutive days in or near Bahía Moreno (Figure 1). The sighting on 10 July (Figure 1, \#3) that consisted of an adult SRW at Juan López observed by a local citizen was not photo-identified, but was assumed to be the same individual following the parsimony principle (Patenaude, 2003). However the potential simultaneous occurrence of a second adult cannot be disproven. It was last observed alone on 11 July 2019. Twenty-eight days later, on 8 August, a local citizen informed us about the presence of a whale with a calf very close to shore north of Antofagasta city. Pictures were taken from land by local citizens. On 12 August we deployed a UAV DJI Phantom 4 pro (DJI Innovation, Shenzhen, China) equipped with a gimbaled camera (1" CMOS, 20M effective pixels). Fitted with a flight controller and equipped with an Android system tablet, 5.5 inch screen, the two intelligent batteries (LiPo 4S, $15.2 \mathrm{~V}, 5870 \mathrm{mAh}$ ) allow a maximum flight time of $25 \mathrm{~min}$ each. During $45 \mathrm{~min}$, high-quality photographs of mother and calf performing typical nursing behavior were registered by the UAV steered from shore (Figure 1, \#6). Markrecapture analysis allowed us to identify unequivocally the mother as the same whale observed a month earlier, due to the presence of the unique white blaze on its dorsum and the callosities pattern (Figure 2b). In order to estimate the relatieve size of the calf we selected the best frame from available UAV videos where the heads of both mother and calf were clear in perpendiular view (Figure 3). The distance from the tip of the rostrum to the posterior border of the blowholes in the calf divided by the equivalent distance in the adult female, resulted in a relative size ratio of the neonate calf $(0.43)$. We deduct that parturition occurred sometime between 11 July and 8 August when the calf was first spotted. It is the use of UAVs by both locals and scientists that provided the high-quality images in July and August 2019 allowing 
positive photo-identification and estimation of the calf as less than half the body length of the mother. Multiple sightings and the mark-recapture of an adult SRW, initially alone and later accompanied by a neonate, in the Antofagasta area, provides strong evidence of in situ calving by the a dult female.

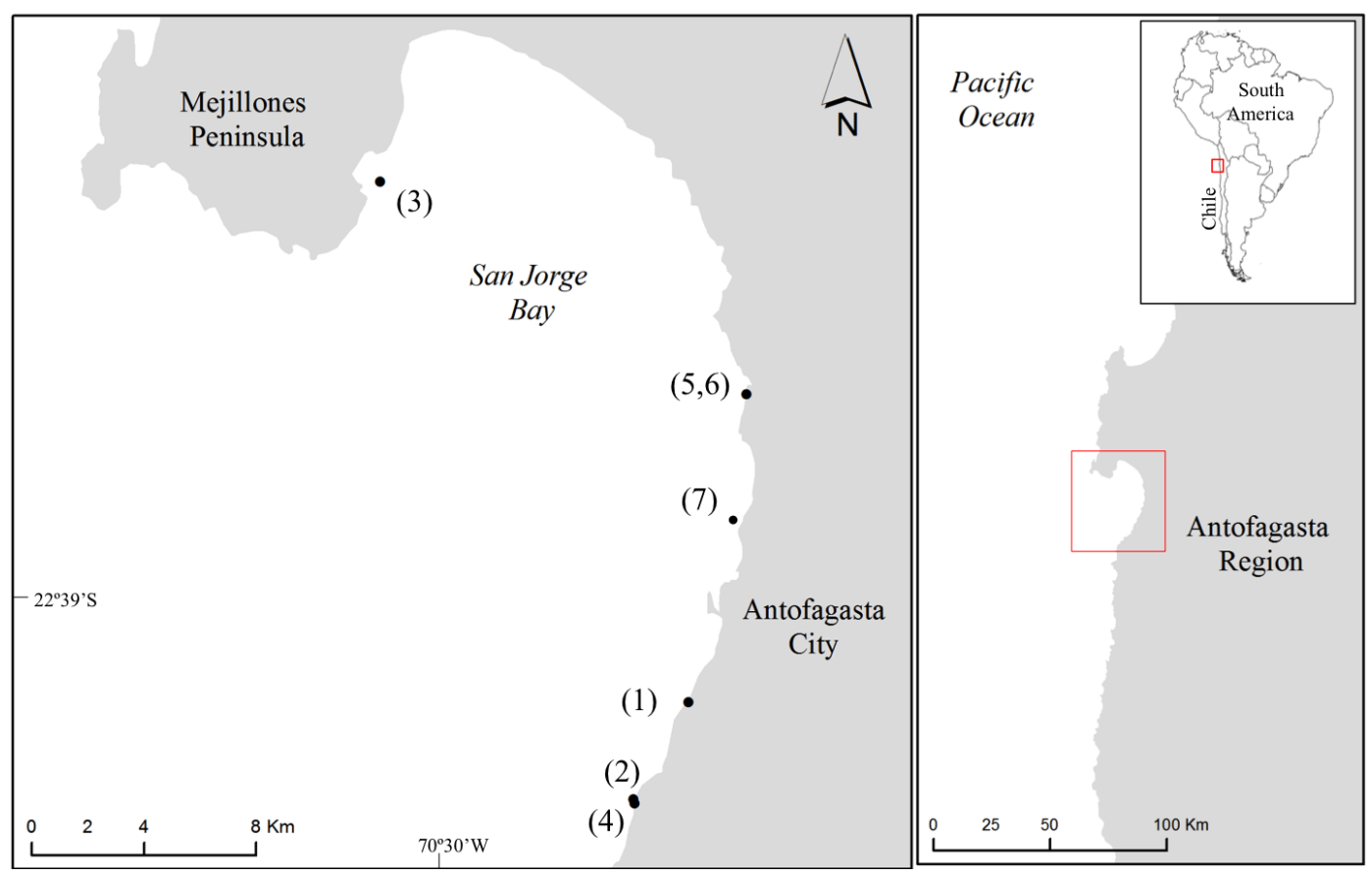

Fig. 1. Study location map showing geographic positions of a SRW seen during 49 days in Bahía Moreno (San Jorge Bay), Antofagasta Region, northern Chile. Black dots indicate positions of the SRW initially (July 2019) observed without calf: (1) 8 July; (2) 9 July; (3) 10 July; (4) 11 July; and subsequently (August 2019) with calf: (5) 8 August; (6) 12 August; (7) 25 August. 


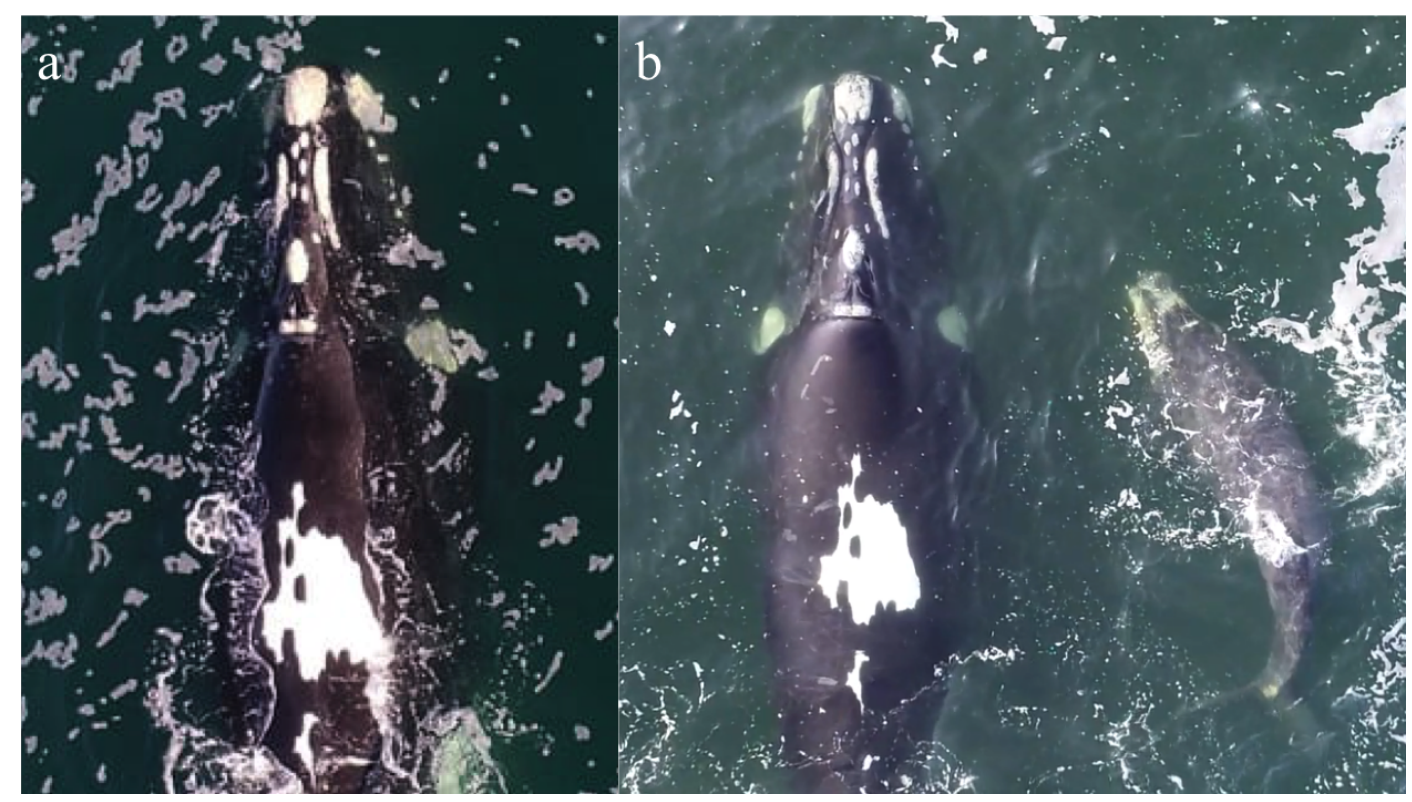

Fig. 2. Mark-recapture of a southern right whale as photographed by UAV near Antofagasta, Chile: (a) Lone adult south of Antofagasta city on 8 July 2019 (photograph courtesy of Arturo Soto); (b) the same individual observed with her calf near Trocadero beach on 12 August 2019.

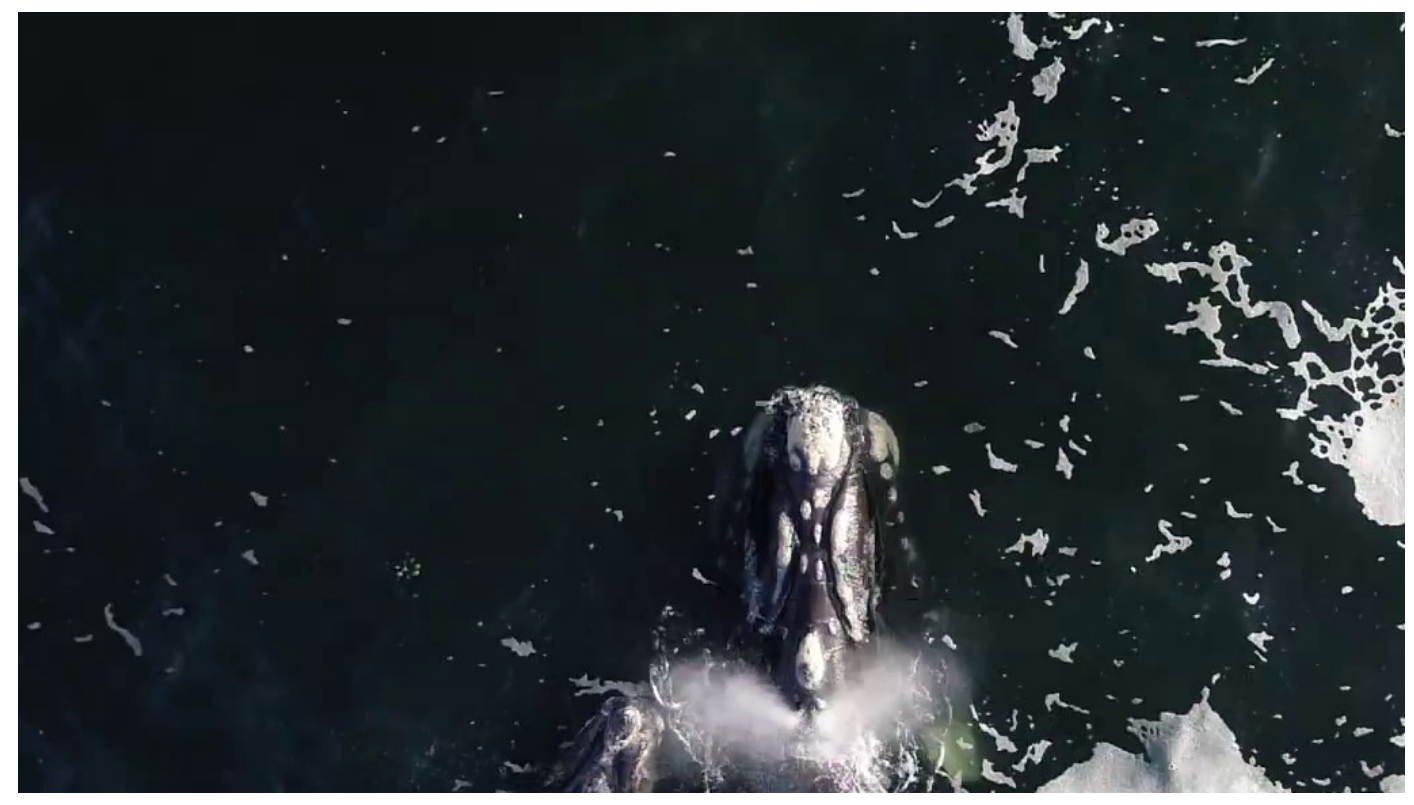

Fig. 3. Image used to assess relative calf size, and age, according to relative

Rare sightings, due to the 'critically endangered' conservation status of the CPe subpopulation, hinder understanding of their true distribution including potential site fidelity. Migratory paths have not been documented but Galletti-Vernazzani et al., (2011) proposed 
that the CPe SRW breeds in two calving areas: one in central and southern Chile $\left(30^{\circ} \mathrm{S}\right.$ to $\left.37^{\circ} \mathrm{S}\right)$ and another in northern Chile $\left(22^{\circ} \mathrm{S}\right.$ to $\left.26^{\circ} \mathrm{S}\right)$. Our findings and earlier observations (Cárdenas et al., 1986; Guerra-Correa et al. 1987) are consistent with the latter. The combined evidence suggests that nearshore coastal areas of the Antofagasta Region may be a habitual calving and nursing ground for CPe SRW. The whales typically remain just a few days at the same coastal location before moving on, whereas a few reported residency patterns lasted longer than a month (Van Waerebeek et al., 1998; Santillán et al., 2004; Galletti-Vernazzani et al., 2014). The fact that the SRW recently observed near Antofagasta remained in the area during minimum 49 days suggests some residency during the early nursing phase, further supported by a 66 day stay of a mother-calf pair in Atico, Peru (Van Waerebeek et al., 1998).

The Antofagasta Region is characterized by the presence of strong coastal upwelling cells, within the Humboldt Current System. The two most important upwelling cells are part of the Mejillones Peninsula Upwelling System (MPUS, around $23^{\circ} \mathrm{S}$ ) (Escribano et al., 2000). Frontal and upwelling systems represent foraging opportunities for cetacean species due to their high productivity and prey concentration (Papastavrou and Van Waerebeek, 1998; Acha et al., 2015). Whereas feeding grounds of the CPe subpopulation are poorly documented, at least some SRW from the Argentina breeding ground are known to feed around South Georgia, the Patagonian shelf and waters of the Polar Front (Leaper et al., 2006; Valenzuela et al., 2018). Historic whaling records of stomach contents of SRW captured in the South Atlantic Ocean showed whales captured north of $40^{\circ} \mathrm{S}$ contained mostly copepods (92\%) while those whales captured south of $50^{\circ} \mathrm{S}$ contained mostly krill (99\%) (Rowntree et al., 2008). This latitudinal shift in diet could be related to the high abundance of krill (Euphausiidae) in the Polar Front during austral summer (Atkinson et al., 2004). A recent study of stable isotopes in SRW from Argentina also revealed euphausiids and copepods as main prey in diets and the presence of three feeding areas for this population at high latitudes (Valenzuela et al., 2018). However, an earlier study of stable isotope $\mathrm{C}^{13}$ in SRW from Argentina showed some whales having high $\mathrm{C}^{13}$ signature values from its baleen plates, which could be interpreted as sporadic feeding in breeding grounds (Rowntree et al., 2008). In northern Chile, the most intense upwelling cells occur in austral spring months (Escribano et al., 2000) and the presence of krill (Euphausia mucronata) along the Humboldt Current System is well-known (Riquelme-Bugueño et al., 2016). Hence, it should be verified whether the calving of SRW in highly productive areas around $23^{\circ} \mathrm{S}$ is merely coincidental, or might be linked to the bonus option of sporadic feeding. 
Little information is published on colouration in CPe SRW. An individual resighted on two different years off Isla de Chiloé showed an unusual gray-morph colouration pattern (GallettiVernazzani et al., 2014). However, the adult female documented here represents the only published SRW record in the SE Pacific with a colouration that includes a large white dorsal blaze contrasting with the otherwise blackish dorsum. None of the animals observed in Peru had such a dorsal blaze (Van Waerebeek et al., 2009; KVW, unpublished data). However, both the mother and calf from Atico showed a pure white ventral blaze in the umbilical area (Van Waerebeek et al., 1998), which is a common feature in the species (Best, 2007). Dorsal white blazes have been reported mainly from the SRW populations in Argentina (1.9\%) and South Africa (7.1\%) (Payne et al., 1983; Schaeff et al., 1999). Extensive shipboard and shoreline surveying in Chile's Fuegian and Patagonian channels and fjords in 1997-2008 indicated that SRW were mostly distributed at the eastern entrance and the central part of the Strait of Magellan and the eastern Beagle Channel, suggesting these whales belong to the SW Atlantic population (Gibbons et al., 2006; Belgrano et al., 2008). Either some CPe SRW also have white blazes or, alternatively, the whale in Bahía Moreno may be of SW Atlantic origin and if so, may be 'recolonizing' the SE Pacific coastal habitat. Recolonization of pre-whaling historic habitats of SRW has been observed in the SW Atlantic population, thus we could expect this from the CPe subpopulation (Arias et al., 2018; Crespo and Coscarella, 2020). More comparative research (e.g. Carroll et al., 2020) including photo-identification and phylogenetic studies of SRW from South Africa, South Georgia, Argentina, Chile-Peru will be needed to understand migratory paths, genetic flux between (sub)populations and degree of philopatry.

Due to slow swimming and nearshore distribution in the breeding season, SRW is the fourth cetacean species most prone to die or be severely injured from vessel collision (Van Waerebeek and Leaper, 2008). Although most lethal collisions occur with vessels that navigate faster than 14 knots (Vanderlaan and Taggart, 2007), this is not exclusive. Entanglement in fishing nets is another major threat for the SRW CPe subpopulation (GallettiVernazzani, 2015). One stranded individual in Chile showed both propeller scars and evidence of net entanglement (Canto et al., 1991), another whale died from a severe entanglement (Galletti-Vernazzani et al., 2017) and a mother-calf pair barely escaped a nearcollision incident with a slower industrial purse-seiner at Pucusana, Lima (Van Waerebeek et al., 2009). Antofagasta Region hosts one of the most important marine traffic routes in northern Chile due to the growth of the (mostly copper) mining industry in the last decade (García-Cegarra and Pacheco, 2019). Recently recommended marine spatial planning to 
mitigate potential collision risk between ships and fin and humpback whales for waters off the northern part of Mejillones Península (Pacheco et al., 2015; García-Cegarra and Pacheco, 2019), if adapted to cover the entire peninsula, might benefit also the CPe. Large cargo vessel speeds in the area exceed the limit of 10 knots allowed in Chilean bays (Garcia-Cegarra and Pacheco, 2019). The nursing of SRW in Bahía Moreno, just north of the major seaport of Antofagasta, hypothetically could endanger their lives. Apart from their proximity to the coast and slow swimming, nursing SRWs typically may not notice, or pay attention to, the presence of speed boats or large cargo vessels (Laist et al., 2001; Nowacek et al., 2004; Van Waerebeek et al., 2009). In Chile at-sea whale-watching of the critically endangered SRW is not allowed and they may only be observed from land (according to Reglamento General de Observación de Mamíferos Reptiles y Aves Hidrobiológicas y del Registro de Avistamiento de Cetáceos D.S.No 38-2011).

In conclusion, this study provides the first evidence of parturition of a SRW in the Antofagasta Region. Furthermore it lends strong support to earlier reports that the area around Antofagasta is an important winter habitat and potentially a key calving/nursing ground for the CPe SRW subpopulation with boundaries yet to be determined. It is not known if the observed nursing of SRW in coastal waters near Antofagasta should be interpreted as an isolated or a recurrent event. Finally, it needs to be investigated whether maritime traffic by artisanal and industrial fishing boats, motor boats, speed boats and large cargo vessels in and around the Antofagasta port could jeopardize the physical integrity and breeding success of visiting SRW. 


\section{Acknowledgements}

We warmly thank Gonzalo Gómez, Roberto Ramirez, and Arturo Soto for the information provided regarding southern right whale sightings in Bahía Moreno. Special thanks also to Alvaro Pinto for the use of UAV and for providing images of a mother-calf pair. Prof. Carlos Guerra-Correa is acknowledged for kindly sharing insights on the presence of southern right whales in the Antofagasta Region, and for introducing one of us (KVW) to this most fascinating study area many years ago. We thank also Barbara Galletti and two anonymous reviewers for their careful review and useful comments on the manuscript.

\section{References}

Acha, E.M., Piola, A., Iribarne, O., Mianzan, H. (2015) Ecological Processes at Marine Fronts. Oases in the Ocean. Springer International Publishing. https://doi.org/10.1007/978$\underline{3-319-15479-4}$

Acevedo-Whitehouse, K., Rocha-Gosselin, A., Gendron, D. (2010) A novel non-invasive tool for disease surveillance of free-ranging whales and its relevance to conservation programs. Animal Conservation 13: 217-225. https://doi.org/10.1111/j.1469-1795.2009.00326.x

Aguayo-Lobo, A. (1974) Baleen whales off continental Chile. In: W.E. Schevill (Ed.). The whale problem: A status report. Cambridge Mass. Harvard University Press 419:209-217.

Aguayo, A., Cardenas, J., Torres, D. (1992) Análisis de los avistamientos de Eubalaena australis (Desmoulins, 1822) en aguas chilenas desde 1983 hasta 1989. Series Científicas Instituto Nacional Antártico Chileno 42: 77-91.

Aguayo, A., and Torres, D. (1986) Records of the southern right whale, Eubalaena australis (Desmoulins 1822) from Chile between 1976 and 1982. Reports of the International Whaling Commission (Special Issue) 10: 159-160.

Aguayo-Lobo, A., D. Torres and J. Acevedo. 1998. Los mamíferos marinos de Chile: I.

Cetacea. Serie Científica Instituto Nacional Antártico Chileno (Chile) 48: 19-159.

Aguayo-Lobo, A., Acevedo, J., Brito, J.L., Olavarría, C., Moraga, R., Olave, C. (2008) La ballena franca del sur, Eubalaena australis (Desmoulins, 1822) en aguas chilenas: análisis de sus registros desde 1976 a 2008. Revista de Biología Marina y Oceanografía 43(3): 653668.http://dx.doi.org/10.4067/S0718-19572008000300024

Arias, M., Coscarella, M.A., Romero, M.A., Sueyro, N., Svendsen G.M., Crespo, E.A., González, R.A. (2018) Southern right whale Eubalaena australis in Golfo San Matías (Patagonia, Argentina): evidence of recolonisation. PlosOne, 13(12): e0207524. doi.org/10.1371/journal.pone.0207524. 
Atkinson, A., Siegel, V., Pakhomov, E., Rothery, P. (2004) Long-term decline in krill stock and increase in salps within the southern ocean. Nature, 432:100-103.

Belgrano, J., Miguel Iñíguez, M., Gibbons, J., García, C., Olavarría, C. (2008)

South-West Atlantic right whales Eubalaena australis (Desmoulins, 1822) distribution nearby the Magellan Strait. Anales Instituto Patagonia (Chile) 36(2):69-74.

Canto, J., Ruiz, P., Cardenas, J.C. (1991). Necropsia de ballena franca austral Eubalaena australis y consideraciones para el manejo de la especie. Boletín Museo Historia Natural Chile 42: 105-111.

Best, P.B. 2007. Whales and dolphins of the Southern African Subregion. Cambridge University Press, Cambridge, UK. 338pp.

Cárdenas, J.C., Torres, D., Oporto, J., Stutzin, M. (1986) Presencia de la ballena franca (Eubalaena australis) en las costas de Chile. Resumen, 2do Reuniao de trabalho de Especialistas em Mamíferos Aquáticos da America do Sul, 4-8 Agosto 1986, Rio de Janeiro, Brasil.

Carroll, E.L., Ott, P.H., McMillan, L.F-, Galletti Vernazzani, B., Neveceralova, P., Vermeulen, E., Gaggiotti, O.E., Andriolo, A., Baker, C.S., Bamford, C., Best, P., Cabrera, E., Calderan, S., Chirife, A., Fewster, R., Flores, P., Frasier, T., Freitas, T., Groch, K., Hulva, P., Dennedy, A., Leaper, R., Leslie, M., Moore, M., Oliveira, L., Seger, J., Stepien, E., Valenzuela, L.O., Zerbini, A., Jackson, J.A. (2020) Genetic diversity and connectivity of southern right whales (Eubalaena australis) found in the Brazil and Chile-Peru wintering grounds and the South Georgia (Islas Georgias del Sur) feeding ground. Journal of Heredity 111(3): 263-276.

Christiansen, F., Sironi, M., Moore, M.J., Di Martino, M., Ricciardi, M., Warick, H.A., Uhart, M.M. (2019) Data from: estimating body mass of free-living whales using aerial photogrammetry and 3D volumetrics, v2, dyard, dataset https://doi.org/10.5061/dyard. M0087p4.

Christiansen, F., Dawson, S.M., Durban, J.W., Fearnbach, H., Miller, C.A., Bejder, L., Uhart, M., Sironi, M., Corkeron, P., Rayment, W., Leunissen, E., Haria, E., Ward, R., Warick, H.A., Kerr, I., Lynn, M.S., Pettis, H.M., Moore, M.J. (2020) Population comparison of right whale body condition reveals poor state of the North Atlantic right whale. Marine Ecology Progress Series 640. Doi: 10.3354/meps 13299.

Clarke, R. (1965) Southern right whales on the coast of Chile. Norsk Hvalfangst-Tidende 54(6): 121-128. 
Cooke, J.G., Rowntree, V.J., Payne, R. (2001) Estimates of demographic parameters for southern right whales (Eubalaena australis) observed off Península Valdés, Argentina. Journal of Cetacean Resarch Management (2): 125-132.

Cooke, J.G. (2018) Eubalaena australis Chile-Peru subpopulation. The IUCN Red List of Threatened $\quad$ Species $2018 . \quad$ http://dx.doi.org/10.2305/IUCN.UK.20181.RLTS.T133704A50385137.en.

Crespo, E.A., Coscarella, M.A. (2020) The southwestern Atlantic southern right whale, Eubalaena australis: updated population rate of increase. Scientific Committee International Whaling Commission SC/68/B, Cambridge, UK, 12.20/5/2020.

Escribano, R., Marin, V.H. and Irribarren, C. (2000) Distribution of Euphausia mucronata at the upwelling area of Peninsula Mejillones, northern Chile: the influence of the oxygen minimum layer. Scientia Marina 64(1): 69-77. https://doi.org/10.3989/scimar.2000.64n169

Frisch-Jordán, A., Ransome, N.L., Aranda-Mena, O. and Romo-Sirvent, F. (2019) Intensive feeding of humpback whales (Megaptera novaeangliae) in the breeding ground of Banderas Bay, Mexico. Latin American Journal of Aquatic Mammals 14(1): 2733.http://dx.doi.org/10.5597/00251

Galletti-Vernazzani, B., Brito, J.L. Cabrera, E., Cardenas, J.C. and Brownell Jr., R.L. (2011) Sightings of southern right whales (Eubalaena australis) off Chile and Peru from 1975 to 2010. Paper SC/S11/RW22 presented to the IWC Scientific Committee, Southern Right Whale Assessment, September 2011. (unpublished). 12pp. [Available from the IWC]

Galletti-Vernazzani, B., Cabrera, E. and Brownell, R. (2014) Eastern South Pacific southern right whale photo-identification catalog reveals behavior and habitat use patterns. Marine Mammal Science 30(1). http://doi.org/10.1111/mms.12030

Galletti-Vernazzani, B. (2015) Progress on the IWC Conservation Management Plan for the Critically Endangered Eastern South Pacific Southern Right Whale Population. Paper $\mathrm{SC} / 66 \mathrm{a} / \mathrm{BRG} / 15$ presented to the IWC Scientific Committee, May 2015 (unpublished). 4pp. [Available from the IWC]

Galletti-Vernazzani, B., Chirife, A., Cabrera, E., Sironi, M. and Brownell Jr., R.L. (2017) Entanglement and death of a Critically Endangered Eastern South Pacific southern right whale (Eubalaena australis) in Chile. Paper SC/67a/HIM/14 presented to the IWC Scientific Committee, May 2017 (unpublished). 10pp. [Available from the IWC]

García-Cegarra, A.M. and Pacheco, A.S. (2019) Collision risk areas between fin and humpback whales with large cargo vessels in Mejillones Bay $\left(23^{\circ} \mathrm{S}\right)$, northern Chile. Marine Policy 103:182-186.https://doi.org/10.1016/j.marpol.2018.12.022 
Gibbons, J., Capella, J.J., Kusch, A. and Cárcamo, J. (2006) The southern right whale Eubalaena australis (Desmoulins, 1822) in the Strait of Magellan, Chile. Anales Instituto Patagonia (Chile) 34:75-80.

https://www.researchgate.net/publication/264549530

Guerra-Correa, C., Van Waerebeek, K., Portflitt, G. and Luna, G. (1987) The presence of cetaceans off northern Chile coast. Estudios Oceanológicos 6:87-96. http://www.vliz.be/nl/datasets-belgische-kust-en-zee?module=ref\&refid=222425

Jiménez Lopez, M.E., Palacios, D.M., Jaramillo-Legorreta, A., Urbán, J., Mate, B.R. (2019) Fin whale movements in the Gulf of California, Mexico, from satellite telemetry. PloS ONE 14(1): e0209324. https://doi.org/10.1371/journal.pone.0209324

Koski, W.R., da-Silva, C.Q., Zeh. J. and Reeves, R.R. (2013) Evaluation of the potential to use capture-recapture analyses of photographs to estimate the size of the Eastern Canada - West Greenland bowhead whale (Balaena mysticetus) population. Canadian Wildlife Biology Management 2(1): 23-25.http://cwbm.name/evaluation-of-the-potential-to-use-capturerecapture-analyses-of-photographs-to-estimate-the-size-of-the-eastern-canada-westgreenland-bowhead-whale-balaena-mysticetus-population/

Laist, D., Knowlton, A.R., Mead, J.G., Collet, A.S., Podesta, M. (2001) Collisions between ships and whales. Marine Mammal Science 17(1):35-75.

Leaper, R., Cooke, J., Trathan, P., Reid, K., Rowntree, V.J. and Payne, R. (2006) Global climate drives southern right whale (Eubalaena australis) population dynamics. Biology Letters 2:289-292.https://doi.org/10.1098/rsbl.2005.0431

Mackintosh, M.A. (1942) The southern stocks of whalebone whales. Discovery Reports 22:197-300.https://doi.org/10.1038/153569a0

Nowacek, D., Johnson, M.P., Tyack, P.L. (2004) North Atlantic right whale (Eubalaena glacialis) ignore ships but respond to altering stimuli. Proceedings of the Royal Society of London. Series B, Biological Science 271:227-231.

Nowacek, D.O., Christiansen, F., Bejder, L., Goldbogen, J.A. and Friedlaender, A.S. (2016) Studying cetacean behaviour new technological approaches and conservation applications. Animal Behavior 120:235-244. https://doi.org/10.1016/j.anbehav.2016.07.019

Orihuela, M., Cortegana-Arias, D. (2013) Registro de un par madre-cría de ballena franca austral (Eubalaena australis) en la costa de Lima, Perú. Revista Peruana de Biología 20(2): 187-188.

Pacheco, A.S., Villegas, V.K., Riascos, J.M. and Van Waerebeek, K. (2015) Presence of fin whales Balaenoptera physalus in Mejillones Bay, a major seaport area in northern Chile. 
Revista Biología Marina y Oceanografía 50(2): 383-391. http://dx.doi.org/10.4067/S071819572015000300017

Patenaude, N. (2003) Sightings of southern right whales around mainland New Zealand.

Science for Conservation 225. 43pp.

Papastavrou, V. and Van Waerebeek, K. (1998) A note on the occurrence of humpback whales (Megaptera novaeangliae) in tropical and subtropical areas: the upwelling link. Report International Whaling Commission 47: 945-47. https://www.researchgate.net/publication/234825770

Pastene, L.A. and Quiroz, D. (2010) An outline of the history of whaling in Chile. Pages 7398 in International center for Folk Culture Studies, ed. Human Culture from the perspective of traditional maritime communities. International symposium Report No. 1. Kanagawa Shimbun Press, Kanagawa, Japan.

https://www.academia.edu/1871805/An_Outline of the History of Whaling in Chile

Payne, R., Rowntree, V.J. and Perkins, J.S. (1990) Population size, trends and reproductive parameters of right whales (Eubalaena australis) off Peninsula Valdes, Argentina. Report of the International Whaling Commission (Special Issue) 12: 271-278. https://ballenas.org.ar/descargas/publicaciones-cientificas/1990/18. Population size, trends and reproductive parameters of right whales \%28Eubalaena australis $\% 29$ off Peninsula Valdes, Argentina.pdf

Piedra, J., Costa, P.L. and Franco-Fraguas, P. (2006) Ballena franca Eubalaena australis en la costa atlántica Urugaya (southern right whales (Eubalaena australis) off the Atlantic coast of Urugay). Buenos Aires Argentina: VIDA SILVESTRE (Sociedad Uruguaya para la Conservación de la Naturaleza).

Reilly, S.B., Bannister, J.L., Best, P.B., Brown, M., Brownell, Jr., R.L., Butterworth, D.S., Clapham, P.J., Cooke, J., Donovan, G.P., Urban, J., Zerbini, A.N. (2008) Eubalaena australis (Chile-Peru subpopulation). In: IUCN 2010. IUCN Red List of Threatened Species. Version 2010.4.

Richardson, W.J., Greene, C.R., Malme, Jr. and Thomson, D.H. (1995) Marine Mammals and Noise. San Diego, CA: Academic Press.

Riquelme-Bugueño, R., Gómez-Gutiérrez, J., Escribano, R., Ruz, P., Hidalgo, P. and Schneider, W. (2016) First measurements of euphausiid growth rates in the northern Humboldt Current (23ㅇ). Revista de Biología Marina y Oceanografía 51(2):435440.http://dx.doi.org/10.4067/S0718-19572016000200020 
Rowntree, V.J., Valenzuela, L.O., Franco-Fraguas, P. and Seger, J. (2008) Foraging behaviour of southern right whales (Eubalaena australis) inferred from variation of carbón stable isotope ratios in their baleen. Journal of Cetacean Research Management SC/60/BRG233. https://ballenas.org.ar/descargas/publicaciones-cientificas/2008/49. Foraging behaviour of southern right whales ....pdf

Santillán, L., Roca, M., Apaza, M., Oliveira, L.R. and Ontón, K. (2004) New record of mother-calf pair of southern right whale, Eubalaena australis, off the Peruvian coast. Latin American Journal of Aquatic Mammals 3(1):83-84.http://dx.doi.org/10.5597/lajam00053

Schaeff, C.M., Best, P.B., Rowntree, V.J., Payne, R., Jarvis, C. and Portway, V.A. (1999) Dorsal skin color patterns among southern right whales (Eubalaena australis): genetic basis and evolutionary significance. Journal of Heredidty 90(4): 464471.https://doi.org/10.1093/jhered/90.4.464

Teal Group Corporation. (2011) World Unmanned Aerial Vehicle Systems: Market Profile and Forecast. Fairfax, VA. Report from the Teal Group Corporation.

Valenzuela, L.O., Sironi, M., Rowntree, V.J., Seger, J. (2009) Isotopic and genetic evidence for culturally inherited site fidelity to feeding grounds in southern right whales (Eubalaena australis). Molecular Ecology 18:782-791.

Vanderlaan, A.S.M. and Taggart, C.T. (2007) Vessel collisions with whales: the probability of lethal injury based on vessel speed. Marine Mammal Science 23(1): 144156.https://doi.org/10.1111/j.1748-7692.2006.00098.x

Van Waerebeek, K. and Leaper, R. (2008) Second report of the IWC Vessel Strike Data Standardisation Working Group. Document SC/60/BC5, Scientific Committee of the International Whaling Commision, Santiago de Chile. 8pp. https://iwc.int/document 1797

Van Waerebeek, K., Reyes, J.C. and Aranda, C. (1992) Southern right whales (Eubalaena australis) off southern Peru. Marine Mammal Science 8(1): 86-88. https://doi.org/10.1111/j.1748-7692.1992.tb00129.x

Van Waerebeek, K., Reyes, J.C. and Van Bressem, M.F. (1998) Sighting of a mother-calf pair of southern right whale Eubalaena australis in Peruvian waters. Estudios Oceanológicos 17:105-107. https://www.researchgate.net/publication/234168488

Van Waerebeek, K., Santillán, L. and Suazo, E. (2009) On the native status of the southern right whale Eubalaena australis in Peru. Boletín del Museo Nacional de Historia Natural, Chile 58: 69-76. http://publicaciones.mnhn.gob.cl/668/w3-article-64569.html 
Weerdt, J. and Ramos, E.A. (2019) Feeding of humpback whales (Megaptera novaeangliae) on the Pacific coast of Nicaragua. Marine Mammal Science 36(1): 285292.https://doi.org/10.1111/mms.12613 
